\title{
Trento, Angelo \\ Imprensa italiana no Brasil, séculos XIX-XX
}

Luigi Biondi*

São Carlos: Ed. UFScar, 2013. Trad. Roberto Zaidan. 276p.

Décadas de pesquisa sobre o tema da imigração italiana, que renderam algumas das obras mais referenciais nesse âmbito historiográfico, levaram Angelo Trento, da Universidade de Nápoles "Istituto Orientale", a aprofundar um dos aspectos centrais para a compreensão do mundo dos imigrantes no Brasil no livro Imprensa Italiana no Brasil, séculos $X I X-X X$, tradução para o português da edição italiana La costruzione di un'identità collettiva. Storia del giornalismo in lingua italiana in Brasile (Viterbo: Archivio Storico dell'Emigrazione Italiana, 2011).

Na sua obra La dov'è la raccolta del caffè, publicada no Brasil com o título Do outro lado do Atlântico (São Paulo: Studio Nobel, 1989), ainda hoje a obra mais completa sobre a história dos italianos no Brasil, na qual a imprensa produzida por eles tomava um espaço temático próprio em alguns capítulos embora atravessasse o livro inteiro como fonte principal, Trento inseriu um apêndice com mais de quatrocentos periódicos italianos publicados no país. Esses foram o ponto de partida para pesquisas sucessivas que levaram Trento, nos últimos anos, a centrar a análise sobre a história dos impressos periódicos em língua italiana no Brasil, durante o século XIX e até a década de 1960. Aquela antiga lista se enriqueceu de mais títulos, encontrados nos arquivos do Brasil, Itália, Holanda e França, e se tornou o corpus documental que fundamenta agora, no seu livro Imprensa italiana no Brasil, uma história exaustiva da expressão escrita, em jornais, pelos imigrantes italianos.

Trento não se limita a tratar essa imprensa como formadora de representações de uma coletividade de imigrantes, indaga sobre os fundamentos sociais dos impressos periódicos e de seus grupos editores e sobre a relação destes com as redes de assinantes, os leitores e a comunidade italiana imigrada em geral. O jornal, além de ser o veículo intencional de transmissão de informações, configura-se como porta-voz e ao mesmo tempo articulador de grupos

\footnotetext{
* Universidade Federal de São Paulo (Unifesp), Escola de Filosofia, Letras e Ciências Humanas (EFLCH), Departamento de História. Guarulhos, SP, Brasil. luigi.biondi@uol.com.br
} 
específicos, utilizando e forjando redes de imigrantes, polo agregador de sua intervenção na nova sociedade. A imprensa étnica como mediadora da transnacionalidade, na qual Trento enfatiza, na melhor tradição historiográfica italiana, suas dinâmicas políticas.

Essa imprensa é estudada também como construtora e expressão de identidades: a nacional - a italianidade - e as regionais, políticas e de classe, todas em suas diferentes e muitas vezes conflitantes versões, todas passando pela via da comum origem num Estado-nação de recente formação. O ser e sentir-se italiano numa experiência de migração por meio da imprensa, declinado em uma miríade de identificações complementares, parece ser o fio condutor de uma trajetória que o autor concentra entre o período da "grande imigração" (1885-1915 aproximadamente) e meados dos anos 1960, quando o longo processo de integração e os fluxos migratórios dos italianos terminam.

Trento dedica mais de metade da obra ao período entre 1880 e a Primeira Guerra Mundial, com dois capítulos iniciais: o primeiro para a imprensa como um todo e o segundo para a imprensa operária. É nessa época que o periódico impresso se configura não somente como órgão de informação, mas também como polo agregador dos próprios imigrantes italianos que chegam em massa ao Brasil. É o período do protagonismo político, comercial e industrial do Brasil urbano, quando o diário em língua italiana Fanfulla, a "joia da coroa” da então colônia ítalo-paulista, narra as vicissitudes da experiência migratória de cerca de um milhão de italianos - e não somente os de São Paulo, pois esse diário, assim como outros periódicos étnicos, era lido para além das fronteiras estaduais. Trento não se limita a estudar o fenômeno migratório nas suas amplas dimensões paulistas, também lança um olhar para as coletividades nos outros estados, para a imprensa italiana desde o Pará até os centros gaúchos e sulinos em geral, nestes bastante difusa.

Nesses dois capítulos, Trento explica a difusão extraordinária de alguns jornais, como os diários Fanfulla e La Tribuna Italiana, e das publicações explicitamente políticas como La Battaglia (anarquista) e Avanti! (socialista), e ao mesmo tempo analisa os vários periódicos que tiveram uma vida difícil, mas que, tomados em conjunto, tornam a expressão escrita da imprensa dos ítalo-brasileiros nesse período importante e significativa, a par de outras como as da Argentina ou dos Estados Unidos.

A separação dessa fase da "grande imigração" em duas esferas temáticas, ao longo de dois capítulos, pretende destacar o papel político da imprensa. No capítulo 1, a grande imprensa e os periódicos culturais, de notícias e multitemáticos, são analisados não somente nos seus aspectos gerais estruturais e 
representativos, supostamente neutros, mas também nas suas atenções ao mundo da grande massa dos imigrantes, incluindo o surgimento de um jornalismo investigativo étnico, que indaga sobre as condições materiais da coletividade, seus anseios e suas expressões políticas. O subcapítulo final introduz uma pesquisa pioneira sobre a imprensa de língua italiana durante a Primeira Guerra Mundial, num momento em que o nacionalismo italiano e a construção da identidade nacional no exterior vivenciam, por causa da guerra, uma intensificação extraordinária, enquanto os imigrantes experimentam novas tensões derivadas da radicalização das lutas operárias.

A “Outra Itália” de esquerda é o tema do capítulo 2, onde o foco é completamente voltado para entender a vida da imprensa em língua italiana que foi expressão de tendências e grupos políticos específicos, ligados ao mundo do trabalho urbano. Sobretudo em São Paulo, mas não somente ali, essa imprensa conseguiu frequentemente se tornar o polo agregador de anarquistas, socialistas, republicanos, radicais e sindicalistas, bem como de trabalhadores em geral. Um protagonismo conhecido na historiografia da história social e política dos trabalhadores no Brasil, que Trento, pela primeira vez após muitos anos, analisa num único capítulo de forma conjunta, coerente e renovada, incorporando as novas pesquisas suas e de outros colegas sobre o tema.

Temos um olhar completo para essa história, sem privilegiar a análise de uma ou de outra tendência, mas as conexões entre elas e o panorama dessa trajetória em sua complexidade, desde as origens, passando pelo auge dos anos 1900-1917, até o declínio no período posterior à Primeira Guerra Mundial, quando a imprensa reflete a diluição dos elementos étnicos da classe operária. Por isso, o autor dedica parte importante desse capítulo ao debate "identidade étnica versus identidade de classe" na imprensa política de língua italiana, tema ainda central nos estudos migratórios e da formação da classe trabalhadora nas Américas.

Na segunda parte do livro, o autor enfrenta a questão da penetração do fascismo na imprensa italiana, sua gradual conquista das redações, sua eliminação em outras, o surgimento e declínio, nas décadas de 1920 e 1930, da imprensa antifascista que viu no Brasil o episódio interessante e multipartidário do jornal La Difesa, enquanto o diário Fanfulla se dobrava aos interesses do governo italiano e ao mesmo tempo continuava se propondo como o porta-voz da italianidade no país. Trento se dedica ao exame de uma imprensa étnica ainda consistente, mas cada vez menor, não comparável em número, qualidade e variedade com a dos primeiros 30 anos republicanos. Uma imprensa que 
progressivamente se fecha em torno das questões ligadas à colônia, mediadora cultural de uma Itália cada vez mais distante e menos frequentada.

A imprensa é estudada para entender a capacidade de adaptação à nova situação brasileira, o equilíbrio entre as influências do fascismo italiano e as tensões derivadas desse posicionamento frente à política nacionalista do Estado Novo e à guerra.

A nova fase que se abre com o pós-guerra se ressente dessa história, de um passado não falado que Angelo Trento analisa no último capítulo, no contexto migratório mais recente, da segunda metade do século XX.

Entre a retomada no Brasil de posições políticas proibidas na nova Itália republicana (o neofascismo no exílio) e a narração da experiência migratória dos anos 1950 e 1960 (até 1965, quando o Fanfulla encerra sua publicação diária), o autor examina o conjunto muito menor de uma imprensa étnica testemunha de uma coletividade italiana imigrada, renovada sim pelos fluxos migratórios do pós-guerra, mas excepcionalmente reduzida.

Trento interpreta a função histórica da imprensa italiana no exterior como expressão viva do mundo dos imigrantes. Ao desaparecer a condição de migrantes, ao sumir gradualmente a operatividade das relações, das redes e das circularidades transnacionais, também essa imprensa deixa de existir. Apesar das dificuldades objetivas na prática da leitura de uma massa imigrante mediamente iletrada, o trabalho de Angelo Trento destaca que foi no período áureo da "grande imigração" que a imprensa étnica italiana mais se desenvolveu, âncora de uma transnacionalidade em ação.

Finalmente, é importante sinalizar que, além do valor da obra como o mais recente e mais aprofundado estudo sobre a história da imprensa italiana no Brasil, o livro se constitui como um recurso de pesquisa fundamental, terminando com um inventário cronológico completo e classificado por estado de mais de oitocentos periódicos em língua italiana publicados no país, onde se indica também a colocação arquivística de cada jornal.

Resenha recebida em 13 de maio de 2015. Aprovada em 25 de agosto de 2015. 